\title{
Climatically controlled chemical and biological development in
}

\section{Arctic lakes}

\author{
Neal Michelutti, ${ }^{1,2}$ Alexander P. Wolfe, ${ }^{1}$ Jason P. Briner, ${ }^{3}$ and Gifford H. Miller ${ }^{4}$ \\ Received 21 December 2006; revised 19 April 2007; accepted 16 May 2007; published 19 July 2007.
}

[1] We investigated the factors controlling lake evolution in Arctic ecosystems using a multiproxy paleolimnological approach on a small lake on Baffin Island, Arctic Canada. Lakewater $\mathrm{pH}$ was inferred from fossil diatom assemblages, whereas primary production was assessed from sediment concentrations of diatom valves and spectrally inferred chlorophyll $a$. Our reconstructed limnological variables registered synchronous changes and showed a close coupling to Holocene climatic fluctuations, as inferred by numerous independent paleoclimate proxies. Without exception, our highest $\mathrm{pH}$ and production values occurred during warm intervals, and vice-versa. A return towards paleolimnological conditions of the warm early Holocene has occurred since the midtwentieth century, corresponding to climate warming following the Little Ice Age. Maximum recent values of our reconstructed parameters are either directly comparable to, or in some cases exceed, values attained during the Holocene Thermal Maximum, $8000-10,000$ years ago. Our data suggest that climate has a first-order influence on primary production and the regulation of in-lake DIC dynamics (and hence on lakewater $\mathrm{pH}$ ) through its modulation of lake ice cover. We conclude that direct forcing by climate is more important than catchment processes in controlling the chemical and biological development of ice-dominated Arctic lake ecosystems, at the scale of the Holocene.

Citation: Michelutti, N., A. P. Wolfe, J. P. Briner, and G. H. Miller (2007), Climatically controlled chemical and biological development in Arctic lakes, J. Geophys. Res., 112, G03002, doi:10.1029/2006JG000396.

\section{Introduction}

[2] Lake ontogeny, which is the limnological counterpart to successional development in terrestrial ecosystems, has long fascinated limnologists because it offers the basis of a general ecological theory and hence a predictive tool for long-term changes in lacustrine systems [Deevey, 1984]. Paleolimnology has been central to the development of lake ontogeny models, largely because it is the primary empirical means of obtaining information concerning processes operating on centennial to millennial timescales. The earliest models based on sedimentary archives proposed the progressive eutrophication of lakes with age [Deevey, 1942]. Subsequent models suggested that Holocene production and organic matter accumulation follow a sigmoidal ontogenetic trajectory, culminating in either paludification or eutrophication [Binford et al., 1983]. More recently, the general view from boreal landscapes glaciated during the Late Pleistocene is that lakes progressively acidify and become

\footnotetext{
${ }^{1}$ Department of Earth and Atmospheric Sciences, University of Alberta, Edmonton, Alberta, Canada.

${ }^{2}$ Now at Department of Biology, Queen's University, Kingston, Ontario, Canada.

${ }^{3}$ Department of Geology, State University of New York, Buffalo, New York, USA.

${ }^{4}$ Department of Geological Sciences and Institute of Arctic and Alpine Research, University of Colorado, Boulder, Colorado, USA.

Copyright 2007 by the American Geophysical Union. 0148-0227/07/2006JG000396\$09.00
}

more oligotrophic, following a transient interval of relatively high production [Engstrom et al., 2000].

[3] In all of these models of lake ontogeny, the role of catchment processes has been deemed critical. For example, base cation sequestration from unweathered glacial deposits is typically invoked as the source of early postglacial alkalinity [Mackereth, 1966; Whitehead et al., 1989; Ford, 1990; Renberg, 1990]. As terrestrial vegetation and soils progressively develop, catchment-supplied dissolved organic carbon (DOC) and nutrients such as nitrogen $(\mathrm{N})$ become increasingly important in driving lake ontogeny. This highlights the intimate linkage between lakes and the successional changes occurring in catchment soils, vegetation, and hydrology. These processes have been illustrated by lacustrine chronosequences spanning boreal landscapes of different age in southern Alaska [Engstrom et al., 2000]. However, far less is known concerning Holocene lake ontogeny in the Arctic where, due to the much sparser tundra vegetation, minimal soil development, continuous permafrost, and persistent lake ice, we hypothesize that the catchment's role in lake development will be severely curtailed.

[4] Here, we use paleolimnology to reconstruct the chemical and biological development of a small lake on Baffin Island in the Canadian Arctic since its inception $\sim 11,000$ years ago. Lakewater $\mathrm{pH}$ is inferred using a diatom-based transfer function, and whole-lake production is assessed from sedimentary concentrations of diatom valves and spectrally inferred chlorophyll $a(\mathrm{Chl} a)$. These data are presented at sufficient temporal resolution (decadal 


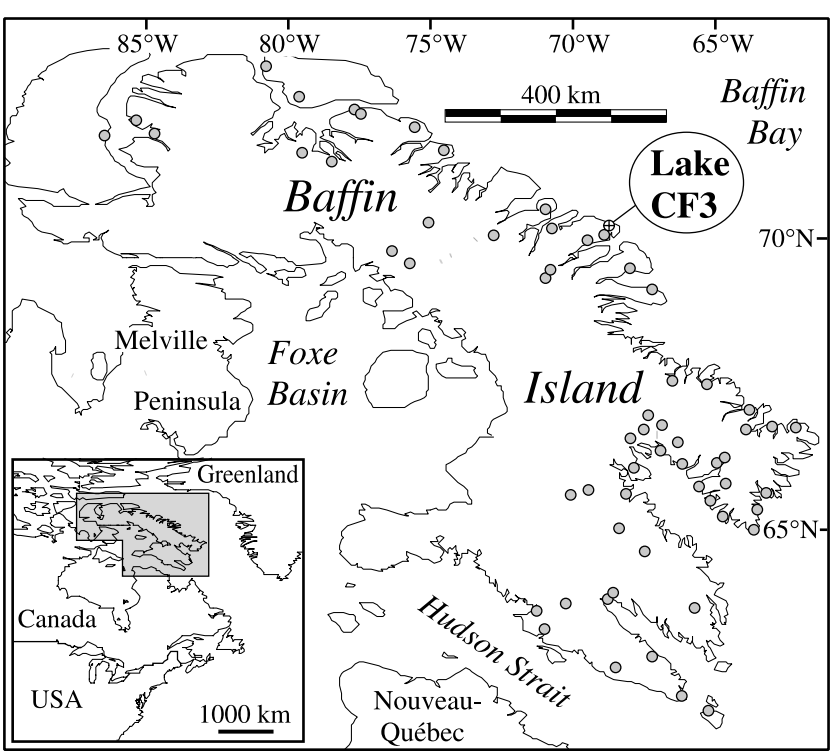

Figure 1. Map showing the location of Lake CF3 on Baffin Island, Nunavut. Black circles are locations of the 60 lakes used to develop the diatom-based $\mathrm{pH}$ inference model [Joynt and Wolfe, 2001]. These training set sites extend at least $400 \mathrm{~km}$ in a north-south transect from Lake CF3, in a strategy aimed to capture, within modern climate space, the range of possible conditions encountered at Lake CF3 over the Holocene.

to centennial throughout) to clearly identify linkages between chemical and biological patterns, and to place recent limnological changes associated with the 'HoloceneAnthropocene' transition in the context of the prior 11 millennia of natural variability. In so doing, we propose a model of lake development for Arctic lakes that is driven, foremost, by climate.

\section{Methods}

\subsection{Site Description}

[5] Lake CF3 $\left(70^{\circ} 31.951^{\prime} \mathrm{N}, 68^{\circ} 22.047^{\prime} \mathrm{W}\right)$ is a small $\left(0.2 \mathrm{~km}^{2}\right)$, shallow $\left(Z_{\max }=7.2 \mathrm{~m}\right)$ tundra lake located near the hamlet of Clyde River on east-central Baffin Island, Nunavut Territory, Arctic Canada (Figure 1). The lake occupies a coastal lowland $(27 \mathrm{~m}$ a.s.l.) within a small catchment of $0.6 \mathrm{~km}^{2}$ that has no permanent inflow or outflow. Lakewater chemistry, from collections obtained in May 2003 and 2005, indicates that the lake is oligotrophic, dilute, and slightly acidic (Table 1 ). As these water samples were recovered from beneath $\sim 2 \mathrm{~m}$ of ice, they reflect limnological conditions of Lake CF3 during late winter, as opposed to summer conditions upon which our paleolimnological inferences are based.

[6] Climate at Clyde River, based on 1971-2000 normals, is categorized as mid-Arctic, with mean annual and July temperatures of $-12.83^{\circ} \mathrm{C}$ and $+4.43^{\circ} \mathrm{C}$, respectively, and mean annual precipitation of $233 \mathrm{~mm} \mathrm{yr}{ }^{-1}$, of which over $80 \%$ falls as snow. Accordingly, extended periods of snow and ice cover characterize lakes in this region, with the open water season lasting less than three months (July-September) in typical years. Present-day vegetation is classified within the prostrate shrub zone of Edlund and Garneau [2000], including Salix spp. and numerous heath taxa (Cassiope tetragona, Empetrum nigrum, Vaccinium uliginosum) amid abundant bryophytes.

[7] Bedrock is composed of Precambrian crystalline lithologies, primarily granite and gneiss. The Clyde forelands surrounding Lake CF3 were covered by the Laurentide Ice Sheet at the Last Glacial Maximum and were deglaciated by $\sim 12000$ yr before present (BP). Cosmogenic exposure dating results and regional terrain mapping indicate that this landscape was glaciated by non-erosive cold-based ice [Briner et al., 2005]. Tills are therefore conspicuously absent and preglacial landforms are preserved. The cryptic signature of this glacial style led previous investigations to conclude that the region was not glaciated during the Last Glacial Maximum [Miller et al., 1977].

[8] Lacustrine, marine, and ice-core proxies from the Baffin Bay region reveal a spatially and temporally coherent pattern of Holocene climate change that appears broadly regulated by summer insolation (Figures 2a-2e). Maximum postglacial warmth occurred between $\sim 10000$ and $8000 \mathrm{yr}$ BP, followed by progressive cooling culminating in Neoglaciation and, ultimately the Little Ice Age (1450-1850 A.D.). Early Holocene summer warmth is captured by the amount of melt on the summit of ice caps [Fisher et al., 1995], attendant decreases of sea ice that allowed range expansions of large cetaceans [Dyke et al., 1996], and the isotopic signature of chitin from chironomid larvae in lake sediments [Wooller et al., 2004]. Chironomid faunal assemblages, obtained from the same sediment cores used in this present study, reveal a pronounced summer Holocene Thermal Maximum as much as $5^{\circ} \mathrm{C}$ warmer than present [Briner et al., 2006] (Figure 2e), in close synchrony with the records illustrated in Figures $2 \mathrm{a}-2 \mathrm{~d}$. Marked warming during the last $\sim 150$ years is driven at least partially by anthropogenic greenhouse gas forcing [Overpeck et al., 1997] (Figure 2f). This most recent warming has been sufficient to induce ecological regime shifts within many Arctic lakes, including those of Baffin Island [Smol et al., 2005; Michelutti et al., 2005].

\subsection{Sediment Processing and Data Analysis}

[9] Our sedimentary analyses were performed on subsamples from the same cores described by Briner et al. [2006]. The sediment stratigraphy is a composite of two

Table 1. Available Water Chemistry Data for Lake CF3

\begin{tabular}{lcc}
\hline \multicolumn{1}{c}{ Variable } & 30 May 2003 & 19 May 2005 \\
\hline $\mathrm{pH}$ & - & 5.89 \\
Conductivity, $\mu \mathrm{S} \mathrm{cm}^{-1}$ & - & 68.90 \\
Chlorophyll $a, \mu \mathrm{g} \mathrm{L}^{-1}$ & 0.98 & - \\
$\mathrm{TP}, \mu \mathrm{g} \mathrm{L}^{-1}$ & 6.10 & 4.60 \\
$\mathrm{TDP}, \mu \mathrm{g} \mathrm{L}^{-1}$ & 2.40 & 1.20 \\
$\mathrm{TN}, \mu \mathrm{g} \mathrm{L}^{-1}$ & 349.34 & 281.03 \\
$\mathrm{TDN}, \mu \mathrm{g} \mathrm{L}^{-1}$ & 261.57 & 236.32 \\
$\mathrm{DOC}, \mathrm{mg} \mathrm{L}^{-1}$ & 3.00 & 1.73 \\
$\mathrm{DIC}, \mathrm{mg} \mathrm{L}^{-1}$ & 0.96 & 1.45 \\
$\mathrm{Cl}^{-}, \mathrm{mg} \mathrm{L}^{-1}$ & 15.28 & 15.15 \\
$\mathrm{SO}_{4}{ }^{2-}, \mathrm{mg} \mathrm{L}^{-1}$ & 2.27 & 2.21 \\
$\mathrm{Na}, \mathrm{mg} \mathrm{L}^{-1}$ & 7.63 & 7.42 \\
$\mathrm{~K}, \mathrm{mg} \mathrm{L}^{-1}$ & 0.84 & 0.84 \\
$\mathrm{Ca}, \mathrm{mg} \mathrm{L}$ & 1.39 \\
$\mathrm{Mg}, \mathrm{mg} \mathrm{L}^{-1}$ & 1.62 & 1.64 \\
$\mathrm{Si}, \mathrm{mg} \mathrm{L}^{-1}$ & 1.45 & 0.14 \\
\hline
\end{tabular}




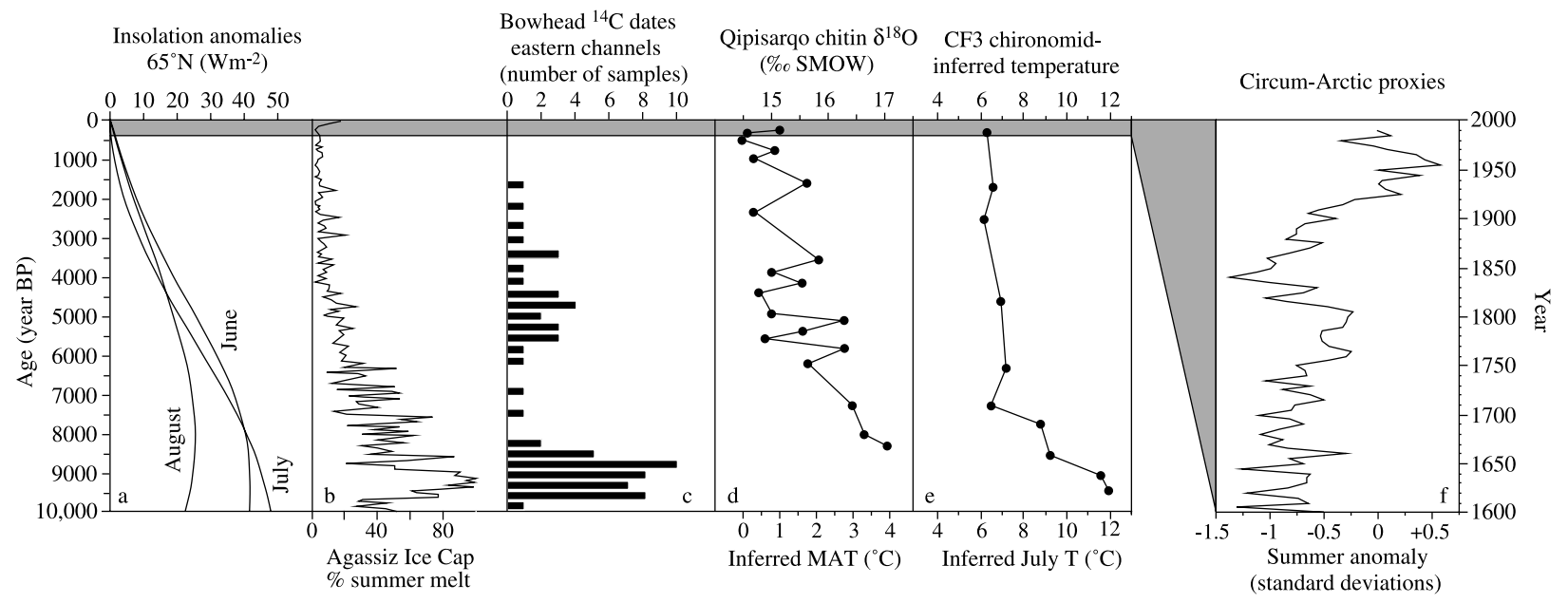

Figure 2. Paleoclimate records from the Baffin Bay region including (a) summer insolation anomalies at $65^{\circ} \mathrm{N}$ [Berger and Loutre, 1991]; (b) percent summer melt record from the Agassiz Ice Cap on Ellesmere Island [Fisher et al., 1995]; (c) frequency distribution of ${ }^{14} \mathrm{C}$ dated bowhead whales in the inter-island channels [Dyke et al., 1996]; (d) chironomid based $\delta^{18} \mathrm{O}$ mean annual temperature record from southwestern Greenland [Wooller et al., 2004]; (e) chironomid-inferred July air temperatures from the Lake CF3 sediment core [Briner et al., 2006]; and (f) inferred circum-arctic summer temperature anomalies for the last four centuries [Overpeck et al., 1997].

cores; a $180 \mathrm{~cm}$ core obtained in May 2002 using a sled mounted percussion coring system [Nesje, 1992], and a $21 \mathrm{~cm}$ surface core with an intact mud-water interface obtained in May 2003 using a modified Kajak-Brinkhurst gravity device [Glew et al., 2001]. Surface sediment samples were extruded on site into $0.5 \mathrm{~cm}$ intervals to $5 \mathrm{~cm}$ depth, then $1 \mathrm{~cm}$ thereafter. The chronology of the percussion core is based on six accelerator mass spectrometry (AMS) ${ }^{14} \mathrm{C}$ ages on aquatic bryophytes (Table 2), which are demonstrably equilibrated with atmospheric $\mathrm{CO}_{2}$ in Arctic lakes within granitic basins [Wolfe et al., 2004]. The surface core was dated with a constant-rate-of-supply (CRS) model using excess ${ }^{210} \mathrm{~Pb}$ activities (Figures $3 \mathrm{a}$ and $3 \mathrm{~b}$ and Table 3 ), and one additional macrophyte AMS ${ }^{14} \mathrm{C}$ age (Table 2). All ${ }^{14} \mathrm{C}$ ages were calibrated to years before present (cal yr BP) using CALIB 5.0.1 [Stuiver and Reimer, 1993]. The two cores were correlated on the basis of their respective radionuclide chronologies, and a composite stratigraphy was created with the upper $13.5 \mathrm{~cm}$ being represented by the surface core. The $2.5 \mathrm{~cm}$ depth in the percussion core corresponded to the interpolated age at $13.5 \mathrm{~cm}$ depth in the surface core, implying the former failed to capture intact the upper $11 \mathrm{~cm}$ (or $\sim 1000$ years) of the record. The master chronology was developed by splicing ${ }^{210} \mathrm{~Pb}$ and ${ }^{14} \mathrm{C}$ dates from the surface core with the youngest ${ }^{14} \mathrm{C}$ date from the percussion core, and by applying linear fits between (1) the ${ }^{14} \mathrm{C}$ ages at $13.5 \mathrm{~cm}$ and $71.5 \mathrm{~cm}$ depths, and $(2)$ the ${ }^{14} \mathrm{C}$ ages at 71.5 and $174.5 \mathrm{~cm}$ depths (Figure 3). All dates were subsequently adjusted to a zero age for $2003 \mathrm{AD}$, when the surface core was collected. All sediment ages mentioned subsequently are expressed in relation to calibrated years before $2003 \mathrm{AD}$ (hereafter yr BP), according to the master chronology (Figure 3c). This chronology was further used to calculate fluxes of certain sediment parameters (diatom valves, spectrally inferred $\mathrm{Chl} a$ ).

\subsection{Diatoms}

[10] Sediments from 19 intervals in the surface core $(0.5 \mathrm{~cm}$ continuous increments from 0 to $5 \mathrm{~cm}$ depth, $1.0 \mathrm{~cm}$ increments from $5 \mathrm{~cm}$ to $14 \mathrm{~cm}$ ) and 61 intervals in the percussion core (sampled either every 2 or $3 \mathrm{~cm}$ ) were prepared for diatom analysis. For each of these 80 samples, freeze-dried splits weighing $200 \mathrm{mg}$ were oxidized with $30 \%$ hydrogen peroxide to remove organic matter, followed by repeated rinsing with distilled water until neutral $\mathrm{pH}$ was achieved. Oxidized sediment slurries were spiked with a known quantity of Eucalyptus pollen in order to estimate sediment diatom concentrations [Wolfe, 1997]. Diluted aliquots from the slurries were dried onto coverslips at

Table 2. Radiocarbon Dates From Lake CF3 Cores

\begin{tabular}{lccccc}
\hline $\begin{array}{c}\text { Midpoint } \\
\text { Depth, }{ }^{\mathrm{a}} \mathrm{cm}\end{array}$ & $\begin{array}{c}\text { Composite Depth, } \\
\mathrm{cm}\end{array}$ & $\begin{array}{c}\delta^{13} \mathrm{C} \\
(\mathrm{ä} \mathrm{PDB})\end{array}$ & $\begin{array}{c}\text { Accession } \\
\text { Number }\end{array}$ & $\begin{array}{c}\text { Radiocarbon Age } \\
\left({ }^{14} \mathrm{C} \text { yr BP }\right)\end{array}$ & $\begin{array}{c}\text { Calibrated Age } \\
(\mathrm{cal} . \mathrm{yr} \mathrm{BP} \pm \sigma)\end{array}$ \\
\hline S-14.5 & $\mathrm{n} / \mathrm{a}$ & -22.7 & CURL-7117 & $1310 \pm 25$ & $1240 \pm 50$ \\
P-2.5 & 13.5 & -20.9 & CURL-6956 & $1240 \pm 30$ & $1180 \pm 80$ \\
P-27.5 & 38.5 & -23.6 & CURL-7049 & $3460 \pm 25$ & $3740 \pm 90$ \\
P-60.5 & 71.5 & -25.0 & CURL-7048 & $6450 \pm 35$ & $7370 \pm 48$ \\
P-98.5 & 109.5 & -25.0 & CURL-7047 & $8150 \pm 40$ & $9070 \pm 50$ \\
P-121.5 & 132.5 & -27.5 & CURL-6955 & $8520 \pm 45$ & $9510 \pm 21$ \\
P-163.5 & 174.5 & -26.0 & CURL-6775 & $9770 \pm 40$ & $11,210 \pm 21$ \\
\hline
\end{tabular}

${ }^{\mathrm{a}} \mathrm{S}$, surface core; $\mathrm{P}$, percussion core. 
Years before $2003 \mathrm{AD} \quad$ Composite $\left({ }^{210} \mathrm{~Pb}\right.$ and cal. $\left.{ }^{14} \mathrm{C}\right)$ years before $2003 \mathrm{AD}$

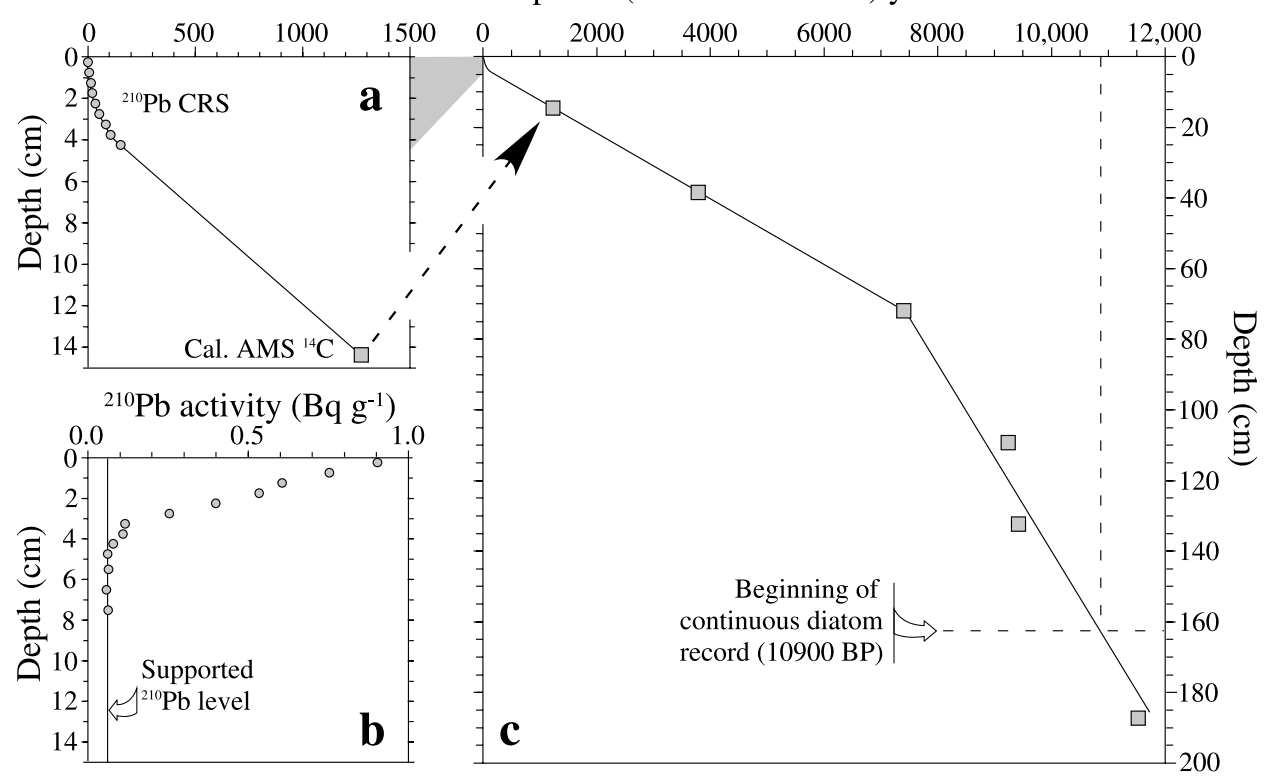

Figure 3. (a) Chronology for the surface core established using a CRS age model applied to the excess ${ }^{210} \mathrm{~Pb}$ inventory shown in Figure 3b, and anchored to one bryophyte AMS ${ }^{14} \mathrm{C}$ age at $14.5 \mathrm{~cm}$. (c) Master chronology of the composite stratigraphy created by splicing the surface and percussion cores on the basis of their respective radionuclide chronologies.

room temperature and mounted to slides using Naphrax medium. A minimum of 300 valves was identified and enumerated at each interval and converted to relative abundances, as well as total diatom concentrations estimated from counting introduced Eucalyptus markers. Taxonomy and nomenclature follow numerous sources cited in our ongoing study of the Baffin Island diatom flora [Joynt and Wolfe, 2001; Briner et al., 2006].

[11] Diatom-inferred $\mathrm{pH}(\mathrm{DIpH})$ reconstructions were derived from the transfer function of Joynt and Wolfe [2001] developed from 60 Baffin Island lakes with similar catchment geology and limnological characteristics to Lake $\mathrm{CF}$. This $\mathrm{pH}$ inference model, based on weighted-averaging calibration and regression, produces a highly significant relationship between measured and diatom-inferred $\mathrm{pH}$ values $\left(r_{\text {boot }}^{2}=0.44, p<0.01, \mathrm{RMSE}_{\text {boot }}=0.34\right)$, which furthermore lacks any trend within residuals $\left(r^{2}=0.00\right)$.

[12] Ordination by detrended correspondence analysis (DCA) was undertaken on down-core diatom relative frequencies, and regressed against $\mathrm{DIpH}$ with the objective of assessing the importance of $\mathrm{pH}$ in structuring diatom communities. DCA is an indirect ordination technique that models species as unimodal responses along synthetic variables (axes) that possess no a priori ecological information, in this way revealing the main directions of variation in fossil assemblages. Thereafter, detrended canonical correspondence analysis (DCCA), the constrained form of DCA, was used to obtain quantitative estimates of species turnover, or $\beta$-diversity, following Smol et al. [2005]. For this calculation, given in standard deviation (SD) units, sample ages assigned from the master chronology (Figure 3c) comprise the sole environmental variable to which diatom assemblages are constrained. The first axis of DCCA obtained this way enables direct comparisons of diatom compositional changes during the Anthropocene (the last $\sim 150$ cal yr BP) to those expressed over the Holocene. All ordinations were undertaken with CANOCO version $4.5 \mathrm{a}$ [ter Braak and Smilauer, 2002].

\subsection{Spectrally Inferred Sediment $\mathrm{Chl} a$}

[13] Sedimentary Chl $a$ reconstructions were inferred using a newly developed application of visible reflectance spectroscopy which relates sediment spectral properties to wet-chemical measurements of pigment concentrations [Michelutti et al., 2005; Wolfe et al., 2006]. Briefly, sediment reflectance spectra between 350 and $2500 \mathrm{~nm}$ were obtained on freeze-dried and sieved core samples $(<125 \mu \mathrm{m})$ using a FieldSpec ${ }^{\mathbb{R}}$ Pro spectroradiometer. Each sample was the average of 10 scans and expressed as \% reflectance relative to a spectralon reference panel. The algorithm developed for Baffin Island lakes by Michelutti et al. [2005] was used to infer total Chl $a$ from sediment spectral data, which includes primary $\mathrm{Chl} a$, Chl $a$ isomers, and the associated degradation products pheophytin $a$ and pheophorbide $a$. This

Table 3. Lead 210 Dating From the Lake CF3 Gravity Core ${ }^{a}$

\begin{tabular}{cccc}
\hline $\begin{array}{c}\text { Core Depth, } \\
\text { cm }\end{array}$ & $\begin{array}{c}\text { Unsupported }{ }^{210} \mathrm{~Pb} \\
\text { Activity, Bq g }\end{array}$ & $\begin{array}{c}\text { Sediment Accum. } \\
\text { Rate, } \mathrm{g} \mathrm{m}^{-2} \mathrm{yr}^{-1}\end{array}$ & $\begin{array}{c}\text { CRS Age, } \\
\text { year AD }\end{array}$ \\
\hline $0.0-0.5$ & 0.850 & 161 & 2003 \\
$0.5-1.0$ & 0.704 & 157 & 1996 \\
$1.0-1.5$ & 0.474 & 160 & 1989 \\
$1.5-2.0$ & 0.853 & 152 & 1983 \\
$2.0-2.5$ & 0.605 & 135 & 1968 \\
$2.5-3.0$ & 0.535 & 138 & 1951 \\
$3.0-3.5$ & 0.159 & 184 & 1920 \\
$3.5-4.0$ & 0.125 & 108 & 1898 \\
$4.0-4.5$ & 0.038 & 69 & 1851 \\
\hline
\end{tabular}

${ }^{\mathrm{a}} \mathrm{No}$ unsupported ${ }^{210} \mathrm{~Pb}$ is present beneath $5 \mathrm{~cm}$. CRS, constant rate of supply. 


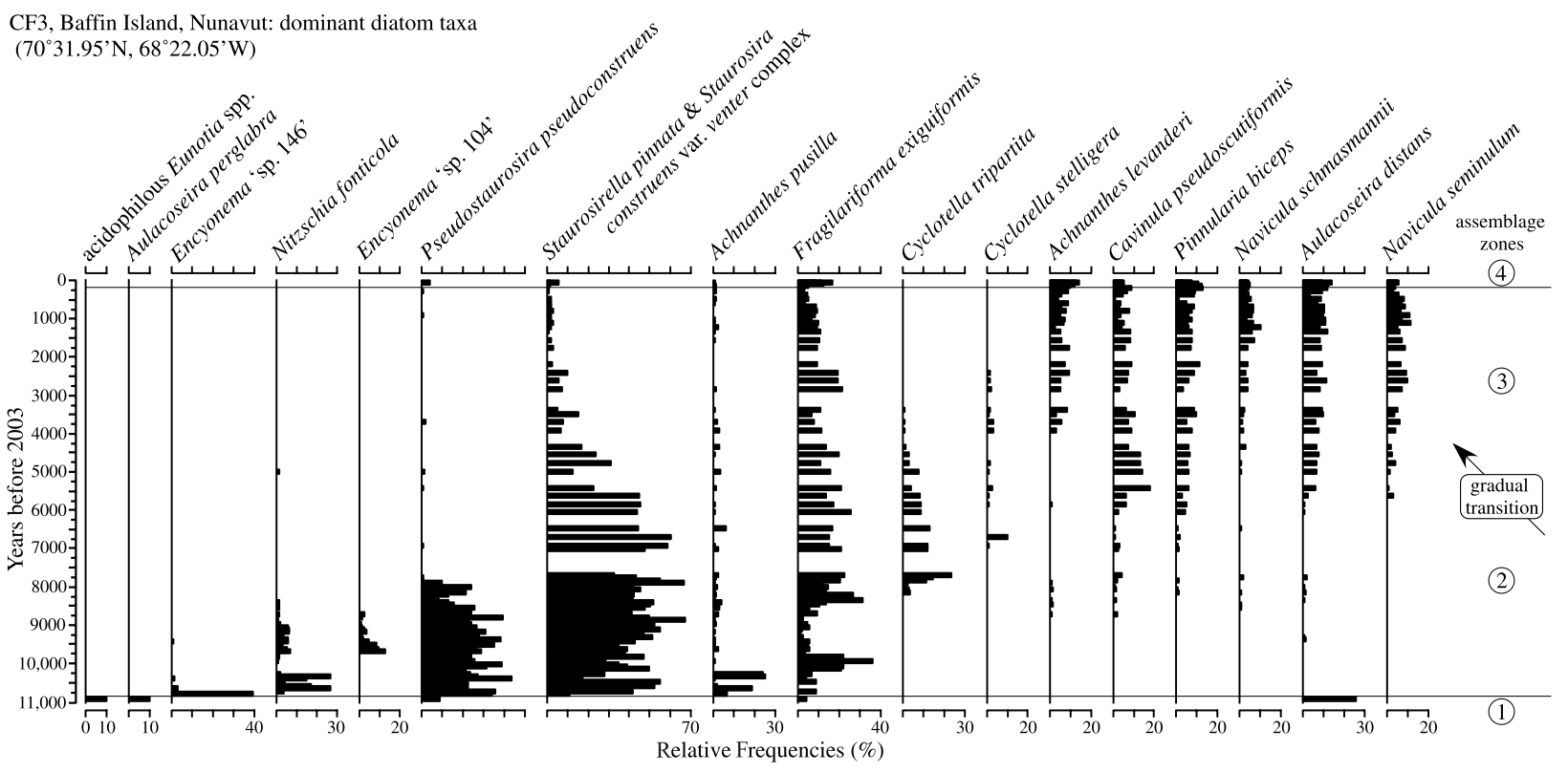

Figure 4. The 10,900 year diatom record from Lake CF3, showing relative frequencies of the 17 most abundant taxa ordered by increasing DCA axis 1 species scores.

spectral technique exploits the depth of the red absorption band preserved in lake sediments $(650-700 \mathrm{~nm})$, which is sensitive to changes in total Chl $a$ concentrations on the order of $0.01 \mathrm{mg} \mathrm{g}^{-1}$ (dry sediment mass). The effects of variable sedimentation rates were adjusted for by calculating fluxes (units $\mathrm{m}^{-2} \mathrm{yr}^{-1}$ ) for both diatom and chlorophyll concentrations.

\section{Results}

\subsection{Sediment Lithology and Chronology}

[14] The lithology of the composite sediment stratigraphy (surface and percussion cores) from Lake CF3 comprises $174 \mathrm{~cm}$ of olive-brown gyttja with scattered mosses, underlain by a $5 \mathrm{~cm}$ layer of moss-rich organic sediment dated to $11,210 \mathrm{cal}$ yr BP. Beneath this, $15 \mathrm{~cm}$ of inorganic fine sand were recovered. Our paleolimnological record begins at the base of the $174 \mathrm{~cm}$ gyttja sequence (ca. 10,900 yr BP), as this corresponds to the earliest record of postglacial diatoms and the start of appreciable concentrations of autochthonous organic matter [Briner et al., 2006]. Sediment accumulation from the base of this gyttja to $70 \mathrm{~cm}$ (ca. $7300 \mathrm{yr} \mathrm{BP}$ ) was relatively rapid $\left(0.31 \mathrm{~mm} \mathrm{yr}^{-1}\right)$, but decreased more than three-fold thereafter $\left(0.093 \mathrm{~mm} \mathrm{yr}^{-1}\right)$ (Figure $3 \mathrm{c}$ ). The excess ${ }^{210} \mathrm{~Pb}$ inventory indicates the last $\sim 150$ years of sediment accumulation was confined to the upper $4.25 \mathrm{~cm}$ (Table 3). The plot of ${ }^{210} \mathrm{~Pb}$ activity versus sediment core depth shows a down-core exponential decay (Figure 3a) characteristic of undisturbed surface sediments.

\subsection{Diatom Stratigraphy}

[15] The state of diatom preservation was excellent throughout the sediment core as there was no evidence of dissolution in even the most lightly silicified taxa. The diatom record from Lake CF3 shows four distinct assemblage zones, assessed visually from the relative frequency data (Figure 4). While the first and last diatom zone boundaries are relatively well-defined biostratigraphically (zones 1-2 and 3-4), the transition between zones 2 to 3 is much more gradual (Figure 4). In zone 1, beginning at ca. $10,900 \mathrm{yr} \mathrm{BP}$, there is a short-lived assemblage composed primarily of acidophilous Aulacoseira taxa, including A. distans and A. perglabra, small acidophilous Eunotia (cf. exigua), and low frequencies of the alkaliphous fragilarioid genera Staurosira and Pseudostaurosira. Although represented by only one sample, this assemblage is crucial because it indicates that the original state of the lake following deglaciation was not highly alkaline. Although slides from samples immediately below this level contained too few diatoms to count, they also contain valves predominantly of acidophilous Aulacoseira and Eunotia taxa. It is noteworthy that a very similar assemblage has been described in the earliest organic sediments from lakes elsewhere on Baffin Island [Wolfe, 1996].

[16] In zone 2, this pioneer assemblage is rapidly replaced by colonial alkaliphilous taxa including Staurosirella pinnata, Staurosira construens var. venter, and Pseudostaurosira pseudoconstruens. These diatoms dominate assemblages for several millennia, until approximately 7800 cal. yr BP in the case of the latter taxon, while that former two remain dominant until 5000 cal. yr BP (Figure 4). These small, benthic Fragilaria sensu lato taxa are common to Arctic lakes, where they are typically associated with high lakewater alkalinity and elevated summer water temperatures [Pienitz et al., 1995, 1999; Weckström et al., 1997; Schmidt et al., 2004]. Additional taxa present during this period in lower frequencies include Fragilariforma exiguiformis, Nitzschia fonticola, and Encyonema species. Two planktonic taxa, Cyclotella tripartita and to a lesser extent $C$. stelligera, also appear during this zone, typically attaining combined relative abundances of around $10 \%$. Autecological data on C. tripartita indicates it is common in slightly acidic water with low dissolved inorganic carbon (DIC) content [Joynt and Wolfe, 2001; Rühland et al., 2003]. 

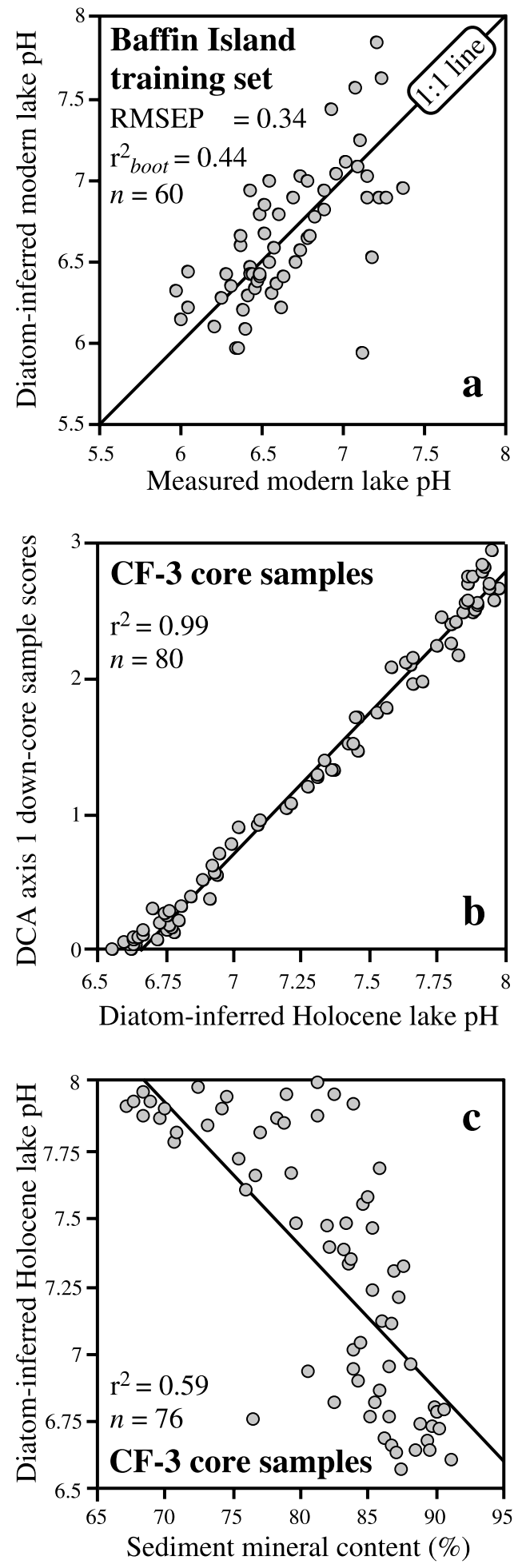

Figure 5. Relationships between (a) diatom-inferred and measured lakewater $\mathrm{pH}$ for the 60 -lake modern training set; (b) DCA axis 1 sample scores from the 80 fossil diatom assemblages enumerated in the Lake CF3 sediment core and their corresponding $\mathrm{DIpH}$ estimates; and (c) Holocene $\mathrm{DIpH}$ and percent sediment inorganic content calculated from loss-on-ignition (LOI) measurements [Briner et al., 2006]. Four of the 80 down-core diatom assemblages lacked LOI from corresponding sediment intervals.
[17] In zone 3, from approximately 7000 cal. yr BP onwards, a gradual transition occurs in diatom assemblages, so that by $4300 \mathrm{yr} \mathrm{BP}$ the dominance of small fragilarioid diatoms ceded to a more diverse, and predominantly acidophilous assemblage consisting of Navicula seminulum, N. schmassmannii, Aulacoseira distans, Pinnularia biceps, Cavinula pseudoscutiformis, and Achnanthes levanderi. In the fourth and final zone representing the uppermost sediments, there is a rebound of the small fragilarioid diatoms that characterized the early to mid-Holocene, in particular Fragilariaforma exiguiformis. Although zone 4 still contains mainly acidophilous taxa, the increase of small fragilarioid diatoms is clearly discernible (Figure 4).

\subsection{Reconstructed Lakewater $\mathrm{pH}$ and Primary Production}

[18] The Baffin Island training set indicates that $\mathrm{pH}$ can be inferred from regional diatom assemblages with a precision of $\pm 0.34 \mathrm{pH}$ units. This bootstrapped error margin originates from weighted-averaging calibration estimates of modern DIpH in the 60-lake training set (Figure 5a). Just over $60 \%$ of the calibration set taxa occur in the sediment core assemblage, and this number rises to $70 \%$ when only the dominant taxa (at least 10\% relative abundance) are considered. Indeed, the $\mathrm{pH}$ transfer function of Joynt and Wolfe [2001] is designed to perform at sites such as Lake CF3, which is located roughly midway in latitude amongst the training set lakes (Figure 1). When this transfer function is applied to the 80 down-core assemblages from Lake CF3, the lowest diatom-rich sample returns a slightly acidic DIpH value (6.6), after which $\mathrm{DIpH}$ jumps rapidly to values between 7.8-8.0 for the ensuing two millennia (Figure 6a). The bottom-most diatom interval is dominated by Aulacoseira distans, A. peglabra, and acidophilous Eunotia species, all of which are well represented in the training set. After peaking in the early Holocene, DIpH progressively declines and the lake becomes acidic at $4300 \mathrm{cal}$. yr BP. This gradual acidification persists until approximately 150 yr BP, after which a slight but steady increase is detected, nearly to the point of neutrality within the last decade (Figure 6a). Although the surface sediment DIpH estimate from Lake CF3 (6.9) is considerably higher than lakewater $\mathrm{pH}$ measured from beneath the ice in May 2005 (5.89, Table 1), we emphasize that DIpH addresses openwater summer conditions, when the training set lakes were sampled, and when primary production approaches its annual high. The $\mathrm{pH}$ of Baffin Island lakes clearly declines during cold conditions, whether these are expressed seasonally or over much longer time scales [Wolfe, 2002]. This phenomenon, which will be reconsidered below, underscores the discrepancy between spring under-ice $\mathrm{pH}$ measured at Lake CF3 and the contemporary sediment $\mathrm{DIpH}$ value. The extremely high correlation observed between down-core DIpH and DCA axis 1 sample scores $\left(r^{2}=0.99, p<0.001\right.$, Figure $\left.5 \mathrm{~b}\right)$ confirms that $\mathrm{pH}$ is the dominant ecological gradient that regulates Holocene diatom assemblage composition in Lake CF3.

[19] Sediment concentrations of spectrally inferred Chl $a$ and diatom valves show remarkably synchronous changes throughout the 10,900-year record, given that they represent independently generated proxies of past aquatic primary production. Both measures, as well as their respective 


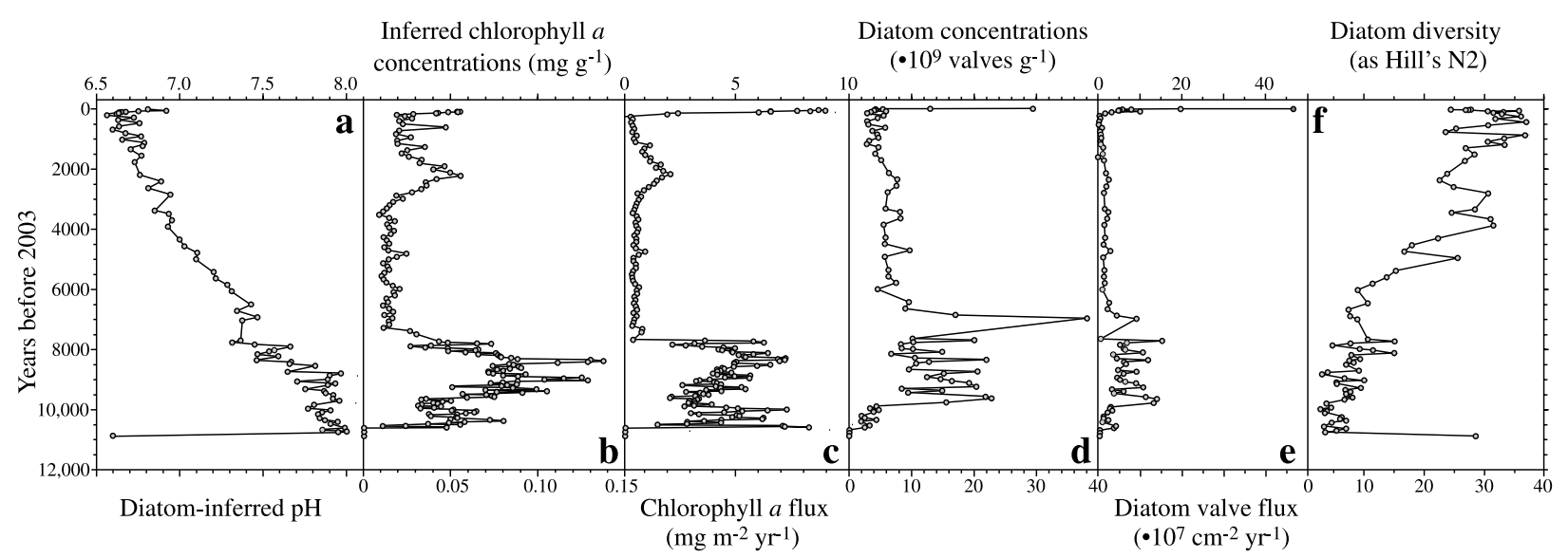

Figure 6. Profiles of (a) DIpH; (b) spectrally inferred total sediment chlorophyll a; (c) sediment chlorophyll $a$ flux; (d) diatom valve concentrations relative to dry mass; (e) diatom valve flux; and (f) diatom diversity expressed by Hill's N2 [ter Braak and Smilauer, 2002], for the composite core from Lake CF3 according to its master chronology.

fluxes, record rapid increases that lag closely the establishment of the lake's initial diatom communities (Figure 6). All of these variables remain high throughout the early Holocene. Rapid declines in Chl $a$ and diatom valve concentrations occur subsequently, around 8000 and 7000 cal. yr BP, respectively. This interval also marks the deceleration of sediment accumulation rates (Figure 3), which indicates that sedimentation in this lake is intimately linked to primary production and autochthonous organic matter supply. Because flux calculations are equally sensitive to changes in concentrations and sedimentation rates, they depict this early to mid-Holocene transition as an abrupt event. In general, all proxies of lake primary production remain low throughout the middle and late Holocene, with values wellbelow those attained prior to $8000 \mathrm{cal}$. yr BP. However, each proxy begins to rise again in the uppermost sediments of the surface core (Figure 6). Once more, it is the fluxes that capture these recent changes most effectively. We note that these fluxes are based on dry mass accumulation rates, so that the effect of elevated water content in near-surface sediments has been eliminated.

\section{Discussion}

\subsection{A Model of Climate-Driven Lake Ontogeny}

[20] Our results challenge whether lake ontogeny in Arctic ecosystems is driven primarily by edaphic processes, as is generally concluded from glaciated boreal regions.

[21] Here we use Lake CF3 as a 'template' for Arctic lake ontogeny, primarily because of the array of proxy data available and tight dating control; however, we note that there are numerous examples of lakes on Baffin Island that show similar ontogenetic processes to those recorded in this study [e.g., Wolfe and Smith, 2004; Wolfe et al., 2000; Miller et al., 1999; Wolfe and Härtling, 1996; Wolfe, 1994].

[22] In glaciated boreal regions, the long-term evolution of lakewater $\mathrm{pH}$ has involved initial contributions of alkalinizing base cations from easily weathered glacial deposits [Mackereth, 1966; Whitehead et al., 1989]. However, in the absence of significant till cover of last-glacial age, and in the presence of highly dilute lake waters, the regulation of acid-base equilibria is more closely dictated by climate. In fact, climate has been demonstrated to exert a first-order control on $\mathrm{pH}$ in several poorly buffered lakes in alpine and Arctic regions [Psenner and Schmidt, 1992; Wolfe, 2002; Larsen et al., 2006; Michelutti et al., 2006]. In these studies, cool intervals have been linked to low lakewater $\mathrm{pH}$, and vice-versa, primarily through regulation of in-lake DIC dynamics. Extended ice cover during cold intervals traps respired $\mathrm{CO}_{2}$ within the water column and inhibits light penetration, which further reduces photosynthetic drawdown of limnetic $\mathrm{CO}_{2}$. The resulting increase of water column $\mathrm{H}_{2} \mathrm{CO}_{3}$ lowers lakewater $\mathrm{pH}$. Conversely, reduced ice cover during warm intervals allows respired $\mathrm{CO}_{2}$ to more freely escape to the atmosphere, while promoting algal production and carbon sequestration, thereby increasing $\mathrm{pH}$.

[23] Ontogenic trends in lake primary production have also been linked to vegetation successional dynamics, specifically changes in available nitrogen generated by enhanced soil fixation under Alnus (alder) thickets [Engstrom et al., 2000]. However, in sparsely vegetated Arctic tundra with few $\mathrm{N}_{2}$-fixers, climate supercedes the influence of edaphic factors on aquatic primary production. This occurs largely through climatic modulation of lake ice cover, which exerts a profound influence on primary producers, because even slight warming will create longer open-water periods and hence growing seasons [e.g., Smol et al., 2005, and references therein].

\subsection{Holocene History of Lake CF3}

[24] The diatom assemblages from the earliest postglacial sediments in Lake CF3 reveal that the lake's initial environment was slightly acidic. This starting point must reflect limited inputs of base cations sourced in the catchment, due to the crystalline nature of the local bedrock and the scarcity of fresh tills due to non-erosive cold-based glaciological regimes. Indeed, if detrital sources of catchment alkalinity were important, the most alkaline period of the lake's history would immediately follow deglaciation. Instead, following a short-lived acidic transient, $\mathrm{pH}$ rose markedly, and remained high (i.e., >7) for thousands of years during the early to middle Holocene. Furthermore, sediment inorganic 


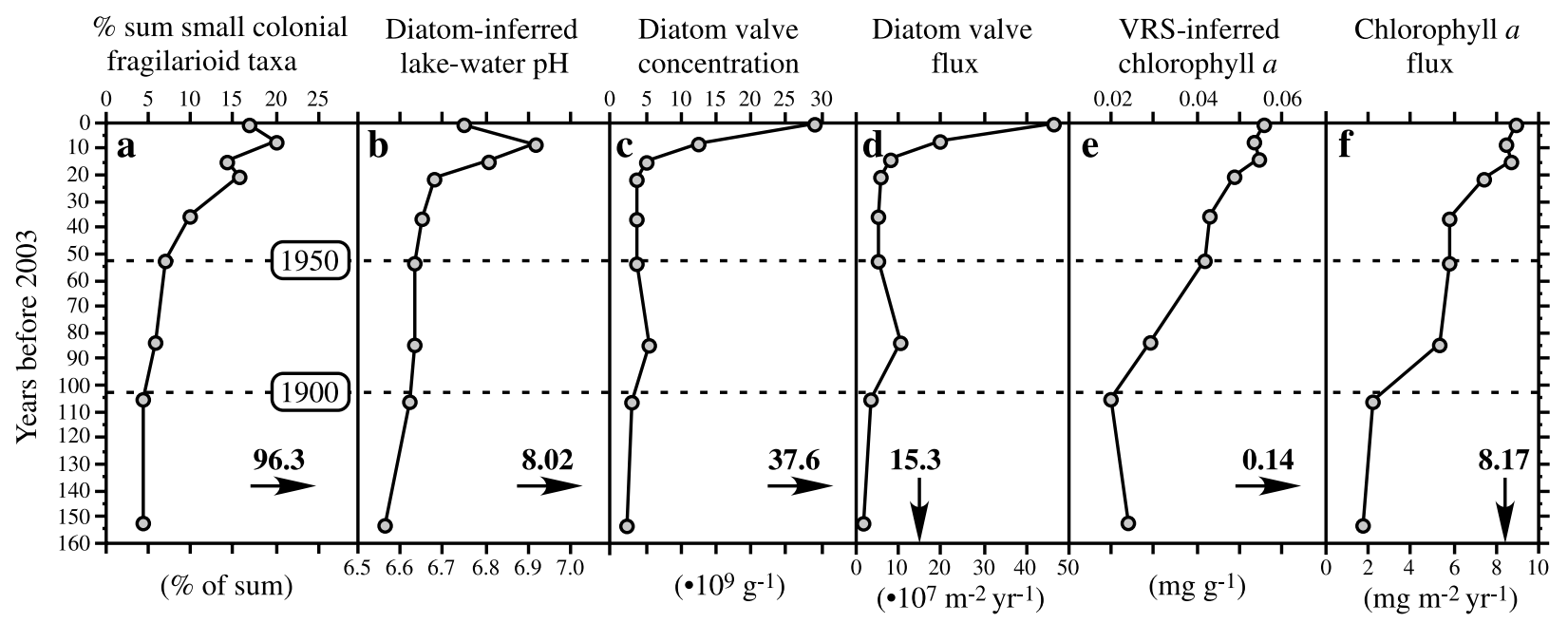

Figure 7. $(\mathrm{a}-\mathrm{f})$ Stratigraphies of the same parameters illustrated in Figure 6, with the addition of summed percentages of alkaliphilous colonial fragilarioid diatoms (Figure 7a), restricted to the last 150 years, and expressed in relation to the CRS ${ }^{210} \mathrm{~Pb}$ chronology. Arrows and bold numbers indicate maximum values attained over the entire 10,900-year record.

content varies inversely with DIpH (Figure 5c), which is contrary to the predicted relationship if mineral erosion were at all involved in alkalinity generation. Indeed, stoichiometry predicts that the biological sequestration of $\mathrm{CO}_{2}$ (aq.) necessary to raise $\mathrm{pH}$ through in-lake processes is proportional to the amount of organic matter buried in sediments, especially in the case of small lakes lacking significant outflow for carbon export, such as Lake CF3. With this in mind, we examine the possibility that delayed soil weathering following deglaciation, and hence of clay mineral production, is the proximate cause for the dramatic $\mathrm{pH}$ changes in the earliest portion of the record (Figure 6a). This is because clays are highly relevant in terms of enhancing organic matter preservation in a variety of depositional environments [Hedges and Keil, 1995]. In Lake CF3 sediments, clays increase from $25 \%$ to $50 \%$ of the mineral fraction around 10,500 cal. yr BP [Briner et al., 2006], concomitantly with increases of $\mathrm{DIpH}$ and sediment photoactive organic matter (Figure 6). However, by 10,000 cal. yr BP clay content returns to values $\sim 40 \%$, which remain remarkably stable throughout the Holocene. This suggests that clays exerted little influence on the preservation of $\mathrm{C}$ sequestered from the water column, and hence on acid-base equilibrium, during the progressive acidification and production declines that characterize the zone $2-3$ transition.

[25] The interval of maximum regional Holocene summer warmth, as reflected by numerous independent paleoclimate proxies (Figure 2), occurred between 10,000 and 8000 cal. yr BP. At this time, elevated lake production accompanied $\mathrm{DIpH}>7.5$, suggesting a tight coupling between climate, biology, and lakewater chemistry. The diatom assemblage changes expressed across the zone 2-3 transition (Figure 4), and attendant DIpH declines (Figure 6a), closely precede regional glacier advances associated with cooling during the Neoglacial [Miller et al., 2005]. The DIpH and primary production proxies all faithfully track this gradual cooling. Palynological evidence from sediment cores throughout Baffin Island reveal that the modern sedge/heath tundra became fully established $\sim 8000$ cal. yr BP, with only minor variations thereafter [Miller et al., 2005; Kerwin et al., 2004]. Thus, it is unlikely that the gradual acidification in Lake CF3 during this time was caused by changes in terrestrial vegetation. Following this cool interval, inferred Chl $a$ and diatom concentrations remain low and show relatively little variability throughout the period of neoglaciation, with the exception of a rise in Chl $a$ around 2500 cal. yr BP (Figures $6 \mathrm{~b}$ and $6 \mathrm{c}$ ). Neoglaciation culminated in the Little Ice Age (XV-XIXth centuries AD), after which climate warmed.

[26] The occurrence of C. tripartita, and to a lesser extent $C$. stelligera, during the onset of cooler conditions around 8000 cal. yr BP (Figure 4) appears contradictory as planktonic taxa are frequently associated with warm conditions [e.g., Smol et al., 2005]. However, autecological data on $C$. tripartita from Baffin Island indicates a slightly acidic $\mathrm{pH}$ optimum of 6.84 [Joynt and Wolfe, 2001], and preference for low DIC $(0.8 \mathrm{mg} / \mathrm{L})$ concentrations [Rühland et al., 2003], consistent with cool conditions and associated $\mathrm{pH}$ declines during this period. The importance of $\mathrm{pH}$ as a driver of diatom species composition in Lake CF3 is shown by the highly significant correlation between DCA axis 1 scores and DI-pH (Figure 5b). Still, autecological data on Arctic diatom taxa is far from complete, and whether the Cyclotella increase is driven by $\mathrm{pH}$ changes or other factors such as decreased erosion and hence increased light penetration, cannot be definitively determined.

[27] Diatom diversity, as estimated by Hill's N2 index, increases during intervals we associate with cold climates, especially the transition from early Holocene warmth to the Neoglacial (Figure 6f). In fact, N2 values closely mirror those of $\mathrm{DIpH}$ throughout the Lake CF3 record. Very similar results have been obtained from Fog Lake on northern Cumberland Peninsula, $500 \mathrm{~km}$ to the southeast of Lake CF3 [Wolfe, 2003]. One hypothesis is that fragmentation of benthic habitats, where small pockets of primarily epipelic diatoms form discrete patches of growth, occurs during cold intervals. This allows a greater number 
Table 4. Summary Results of Detrended Canonical Correspondence Analysis (DCCA) of Anthropocene and Holocene Diatom Assemblages Constrained to Time of Deposition (From the Age Model) as the Sole Environmental Variable ${ }^{\text {a }}$

\begin{tabular}{ccccc}
\hline & $\begin{array}{c}\text { DCCA Axis 1 Gradient Length } \\
\text { Interval }\end{array}$ & \multicolumn{1}{c}{$\lambda_{1}$} & $\lambda_{1} / \lambda_{2}$ & $P$ \\
\hline Anthropocene $(0-150 \mathrm{cal} \mathrm{yr} \mathrm{Bp})$ & 1.00 & 0.09 & 1.17 & 0.003 \\
Holocene $(0-10,900 \mathrm{cal}$ yr Bp) & 2.809 & 0.519 & 3.604 & 0.001 \\
\hline
\end{tabular}

${ }^{\text {a }}$ Significance of the ordination results $(P)$ is obtained by Monte Carlo permutation tests (499 random permutations).

of taxa to flourish, albeit at lower levels of success in terms of total production relative to warm and species-poor intervals dominated by a few highly competitive taxa. Spatial fragmentation of benthic habitats has been observed in Eunotia and Pinnularia species in lakes elsewhere on Baffin Island [Wolfe, 1996].

[28] The model of climate-driven lake ontogeny presented here appears wholly validated by trends of the most recent decades, in which all proxies return to their 'warm' states, with respect to $\mathrm{pH}$ and primary production. The rapidity of recent changes, coupled to the absence of corresponding changes in sediment lithology, strongly imply they are not regulated by catchment processes. The ${ }^{210} \mathrm{~Pb}$ chronology of these most recent changes and their relatively high stratigraphic resolution (Figure 7) indicate considerable synchrony with the history of recent Arctic warming (Figure 2f). Furthermore, the trend towards more productive limnological states in Baffin Island lakes is apparently widespread. A survey of 6 additional lakes near Clyde River on Baffin Island all reveal sharp recent increases in spectrally inferred Chl a [Michelutti et al., 2005]. With current climate warming and prolongation of the ice-free growing season, continued alkalinization of lakes is predicted as primary production increases apace. For example, the Lake CF3 results are directly compatible with detailed records from Finnish Lapland [Weckström et $a l ., 2006]$, the alpine zone of central Norway [Larsen et al., 2006], and Boothia Peninsula in central Nunavut [LeBlanc et al., 2004], where recent increases of alkaliphilous fragilariod taxa are reminiscent of early Holocene assemblages. But the likelihood seems equally great that anthropogenic atmospheric deposition may interfere, via either positive or negative feedbacks, with the above processes. Anthropogenic fluxes of strong acid anions to eastern Baffin Island are non-negligible, exceeding $50 \mathrm{~kg} \mathrm{~km}^{-2} \mathrm{yr}^{-1}$ for both nitrate and sulfate [Goto-Azuma and Koerner, 2001]. While inorganic nitrogen deposition is almost certain to induce some level fertilization both on land and in lakes (which may or may not be transient), sulfate deposition necessarily implies acidification potential. A remaining question is the fate of pollutants already archived in regional glaciers that are undergoing rapid melt [e.g., Blais et al., 2001].

\subsection{Anthropocene and Arctic Lake Ontogeny}

[29] The results of DCCA ordination applied to the Lake CF3 diatom assemblages constrained to time help assess the extent of anthropogenic changes in the context of the Holocene. Because time is the only predictor variable used in these ordinations, the fit of axis 1 with respect to diatom assemblages is highly significant $(p<0.005)$. The analysis for the last 150 years produced an axis 1 gradient length, or $\beta$-diversity, of 1.002 SD units (Table 4), which is directly comparable with many sites from the circumpolar Arctic, and slightly higher than the benchmark for undisturbed boreal lakes (0.98 SD units [Smol et al., 2005]). However, the gradient length for the complete 10,900-year diatom record is $2.809 \mathrm{SD}$ units, which implies that recent rates of diatom compositional turnover are about a third of that accomplished since deglaciation. We believe this finding is probably typical for a large fraction of Arctic lakes, likely the majority, based on our recent multiple-lake studies [Michelutti et al., 2005; Smol et al., 2005]. However, the results from Lake CF3 are the first to place these recent changes explicitly in the context of the entire postglacial record of lake ontogeny. Indeed, we have developed the most highly resolved paleolimnological record to date for the Artic, exceeded by only select northern hemisphere sites [Renberg, 1990].

[30] Two of six paleolimnological variables that demonstrably track lake development are currently at levels beyond any encountered in the last 10,900 years (Figure 7). Thus, there remains little doubt that marked deviations from natural trajectories of lake ontogeny have already occurred in the Arctic during the Anthropocene. We view the feedbacks operating between climate, primary production, and water chemistry as the central drivers of lake ontogeny on Baffin Island, largely outweighing the importance of catchment processes in terms of long-term biogeochemical regulation. Although the key limnological processes involved have clearly been sensitive to Holocene climate variability, and although we now understand the directions of biological and chemical shifts in relation to climate change, we remain incapable of predicting how the future will unfurl for lakes such as Lake CF3. This is because the current pace of climate change in the Arctic, amid uncertain futures with respect to anthropogenic atmospheric emissions, will conspire to produce an environment with no historical precedent.

[31] Acknowledgments. This work was primarily supported by NSERC and C/BAR awards to N.M. and A.P.W. We are grateful to residents of Clyde River, the Nunavut Research Institute (Nunavummi Qaujisaqtulirijikkut, Government of Nunavut, Iqaluit), NSF, and VECO for logistical support. We further thank Thom Davis for assisting with fieldwork, Kris Hadley for sediment processing, and Benoit Rivard for spectroradiometry.

\section{References}

Berger, A., and M. F. Loutre (1991), Insolation values for the climate of the last 10 million years, Quat. Sci. Rev., 10, 291-310.

Binford, M. W., E. S. Deevey, and T. L. Crisman (1983), Paleolimnology: An historical perspective on lacustrine ecosystems, Ann. Rev. Ecol. Syst., 14, 255-286.

Blais, J. M., D. W. Schindler, D. C. G. Muir, M. Sharp, D. Donald, M. Lafrenière, E. Braekevekt, and W. M. J. Strachan (2001), Melting glaciers: a major source of persistent organochlorines to subalpine Bow Lake in Banff National Park, Canada, Ambio, 30, 410-415.

Briner, J. P., G. H. Miller, P. T. Davis, and R. Finkel (2005), Cosmogenic exposure dating in Arctic glacial landscapes: implications for the glacial history of northeastern Baffin Island, Arctic Canada, Can. J. Earth Sci., $42,67-84$. 
Briner, J. P., N. Michelutti, D. R. Francis, G. H. Miller, Y. Axford, M. J. Wooller, and A. P. Wolfe (2006), A multi-proxy lacustrine record of Holocene climate change on northeastern Baffin Island, Arctic Canada, Quat. Res., 65, 431-442.

Deevey, E. S. (1942), Studies on Connecticut lake sediments. III. The biostratonomy of Linsley Pond, Am. J. Sci., 240, 233-264.

Deevey, E. S. (1984), Stress, strain, and stability of lacustrine ecosystems, in Lake Sediments and Environmental History, edited by E. Y. Hayworth and J. W. G. Lund, pp. 203-229, Univ. of Minnesota Press, Minneapolis.

Dyke, A. S., J. Hooper, and J. M. Savelle (1996), A history of sea ice in the Canadian Arctic archipelago based on postglacial remains of the bowhead whale (Balaena mysticetus), Arctic, 49, 235-255.

Edlund, S. A., and M. Garneau (2000), Overview of vegetation zonation in the Arctic, in Environmental Response to Climate Change in the Canadian High Arctic, edited by M. Garneau and B. T. Alt, Geol. Surv. Can. Bull., 529, 113-127.

Engstrom, D. R., S. C. Fritz, J. E. Almendinger, and S. Juggins (2000), Chemical and biological trends during lake evolution in recently deglaciated terrain, Nature, 408, 161-166.

Fisher, D. A., R. M. Koerner, and N. Reeh (1995), Holocene climate records from the Agassiz Ice Cap, Ellesmere Island, NWT, Canada, Holocene, 5 , $19-24$.

Ford, M. S. J. (1990), A 10,000-yr history of natural ecosystem acidification, Ecol. Monogr., 60, 57-89.

Glew, J. R., J. P. Smol, and W. M. Last (2001), Sediment core collection and extrusion, in Basin Analysis, Coring and Chronological Techniques, vol. 1, edited by W. M. Last and J. P. Smol, pp. 73-105, Springer, New York.

Goto-Azuma, K., and R. M. Koerner (2001), Ice core studies of anthropogenic sulfate and nitrate trends in the Arctic, J. Geophys. Res., 106, 4959-4969.

Hedges, J. I., and R. G. Keil (1995), Sedimentary organic matter preservation-an assessment and speculative synthesis, Mar. Chem., 49, 81-115.

Joynt, E. H., III, and A. P. Wolfe (2001), Paleoenvironmental inference models from sediment diatom assemblages in Baffin Island lakes (Nunavut, Canada) and reconstruction of summer water temperature, Can. J. Fish. Aquat. Sci., 58, 1222-1243.

Kerwin, M. K., J. T. Overpeck, R. S. Webb, and K. H. Anderson (2004), Pollen-based summer temperature reconstructions for the Eastern Canadian Boreal forest, Sub-Arctic and Arctic, Quat. Sci. Rev., 23, $1901-1924$.

Larsen, J., V. J. Jones, and W. Eide (2006), Climatically driven pH changes in two Norwegian alpine lakes, J. Paleolimnol., 36, 175-187.

LeBlanc, M., K. Gajewski, and P. B. Hamilton (2004), A diatom-based Holocene paleoenvironmental record from a lake on the Boothia Peninsula, Nunavut, Canada, Holocene, 14, 423-431.

Mackereth, F. J. H. (1966), Some chemical observations on post-glacial lake sediments, Philos. Trans. R. Soc. London, Ser. B, 250, 165-213.

Michelutti, N., A. P. Wolfe, R. D. Vinebrooke, B. Rivard, and J. Briner (2005), Recent primary production increases in Arctic lakes, Geophys. Res. Lett., 32, L19715, doi:10.1029/2005GL023693.

Michelutti, N., M. S. V. Douglas, A. P. Wolfe, and J. P. Smol (2006), Heightened sensitivity of a poorly-buffered high Arctic lake to lateHolocene climatic change, Quat. Res., 65, 421-430.

Miller, G. H., J. T. Andrews, and S. K. Short (1977), The last interglacialglacial cycle, Clyde foreland, N.W.T.: Stratigraphy, biostratigraphy, and chronology, Can. J. Earth Sci., 14, 2824-2857.

Miller, G. H., W. N. Mode, A. P. Wolfe, P. E. Sauer, O. Bennike, S. L. Forman, S. K. Short, T. W. Stafford Jr., and K. M. Williams (1999), Stratified interglacial lacustrine sediments from Baffin Island, Arctic Canada: chronology and paleoenvironmental implications, Quat. Sci. Rev., 18, 789-810.

Miller, G. H., A. P. Wolfe, J. P. Briner, P. E. Sauer, and A. Nesje (2005), Holocene glaciation and climate evolution of Baffin Island, Arctic Canada, Quat. Sci. Rev., 24, 1703-1721.

Nesje, A. (1992), A piston corer for lacustrine and marine sediments, Arct. Alp. Res., 24, 257-259.

Overpeck, J., et al. (1997), Arctic environmental change of the last four centuries, Science, 278, 1251-1256.

Pienitz, R., J. P. Smol, and H. J. B. Birks (1995), Assessment of freshwater diatoms as quantitative indicators of past climatic change in the Yukon and Northwest Territories, Canada, J. Paleolimnol., 13, 21-49.

Pienitz, R., J. P. Smol, and G. M. MacDonald (1999), Paleolimnological reconstruction of Holocene climatic trends from two boreal treeline lakes, Northwest Territories, Canada, Arct. Antarct. Alp. Res., 31, 82-93.

Psenner, R., and R. Schmidt (1992), Climate-driven pH control of remote alpine lakes and effects of acid deposition, Nature, 356, 781-783.
Renberg, I. (1990), A 12600 year perspective on the acidification of Lilla Öresjön, southwest Sweden, Philos. Trans. R. Soc. London, Ser. B, 327 , $357-361$

Rühland, K., J. P. Smol, and R. Pienitz (2003), Ecology and spatial distributions of surface-sediment diatoms from 77 lakes in the subarctic Canadian treeline region, Can. J. Bot., 81, 57-73.

Schmidt, R., C. Kamenik, H. Lange-Bertalot, and R. Klee (2004), Fragilaria and Staurosira (Bacillariophyceae) from sediment surfaces of 40 lakes in the Austrian Alps in relation to environmental variables, and their potential for paleoclimatology, J. Limnol., 63, 171-189.

Smol, J. P., et al. (2005), Climate-driven regime shifts in the biological communities of Arctic lakes, Proc. Natl. Acad. Sci., 102, 4397-4402.

Stuiver, M., and P. J. Reimer (1993), Extended C-14 database and revised CALIB 3.0 C-14 age calibration program, Radiocarbon, 35, 215-230.

ter Braak, C. J. F., and P. Smilauer (2002), CANOCO reference manual and CanoDraw for Windows user's guide: software for Canonical Community Ordination (version 4.5), Microcomputer Power, Ithaca, N. Y.

Weckström, J., A. Korhola, and T. Blom (1997), Diatoms as quantitative indicators of $\mathrm{pH}$ and water temperature in subarctic Fennoscandian lakes, Hydrobiologia, 347, 171-184.

Weckström, J., A. Korhola, P. Erästö, and L. Holmström (2006), Temperature patterns over the past eight centuries in Northern Fennoscandia inferred from sedimentary diatoms, Quat Res., 66, 78-86.

Whitehead, D. R., D. F. Charles, S. T. Jackson, J. P. Smol, and D. R. Engstrom (1989), The developmental history of Adirondack (N.Y.) Lakes, J. Paleolimnol., 2, 185-206.

Wolfe, A. P. (1994), Late Wisconsinan and Holocene diatom stratigraphy from Amarok Lake, Baffin Island, N.W.T., Canada, J. Paleolimnol., 10, $129-139$.

Wolfe, A. P. (1996), A high-resolution late-glacial and early Holocene diatom record from Baffin Island, eastern Canadian Arctic, Can. J. Earth Sci., 33, 928-937.

Wolfe, A. P. (1997), On diatom concentrations in lake sediments: results of an inter-laboratory comparison and other experiments performed on a uniform sample, J. Paleolimnol., 18, 61-66.

Wolfe, A. P. (2002), Climate modulates the acidity of Arctic lakes on millennial time scales, Geology, 30, 215-218.

Wolfe, A. P. (2003), Diatom community responses to late Holocene climatic variability, Baffin Island, Canada: a comparison of numerical methods, Holocene, 13, 29-37.

Wolfe, A. P., and J. W. Härtling (1996), The late Quaternary development of three ancient tarns on southwestern Cumberland Peninsula, Baffin Island, Arctic Canada: paleolimnological evidence from diatoms and sediment chemistry, J. Paleolimnol., 15, 1-18.

Wolfe, A. P., and I. R. Smith (2004), Paleolimnology of the Canadian Arctic Archipelago, in Long-Term Environmental Change in Arctic and Antarctic Lakes, edited by R. Pienitz, M. S. V. Douglas, and J. P. Smol, pp. 241-268, Springer, New York.

Wolfe, A. P., B. Fréchette, P. J. H. Richard, G. H. Miller, and S. L. Forman (2000), Paleoecological Assessment of a $>90,000$-year record from Fog Lake, Baffin Island, Arctic Canada, Quat. Sci. Rev., 19, 1677-1699.

Wolfe, A. P., G. H. Miller, C. Olsen, S. L. Forman, P. T. Doran, and S. U. Holmgren (2004), Geochronology of high latitude lake sediments, in Long-Term Environmental Change in Arctic and Antarctic Lakes, edited by R. Pienitz, M. S. V. Douglas, and J. P. Smol, pp. 19-52, Springer, New York.

Wolfe, A. P., R. D. Vinebrooke, B. Rivard, N. Michelutti, and B. Das (2006), Experimental calibration of lake-sediment spectral reflectance to chlorophyll a concentrations: methodology and paleolimnological validation, J. Paleolimnol., 36, 91-100.

Wooller, M. J., D. Francis, M. L. Fogel, G. H. Miller, I. R. Walker, and A. P. Wolfe (2004), Quantitative paleotemperature estimates from $\delta^{18} \mathrm{O}$ of chironomid head capsules preserved in Arctic lake sediments, J. Paleolimnol., $31,267-274$

J. P. Briner, Department of Geology, State University of New York, Buffalo, NY 14260, USA.

N. Michelutti, Department of Biology, Queen's University, Kingston, ON, Canada M5S 3B1. (michelut@biology.queensu.ca)

G. H. Miller, Department of Geological Sciences and Institute of Arctic and Alpine Research, University of Colorado, Boulder, CO 80309-0450, USA.

A. P. Wolfe, Department of Earth and Atmospheric Sciences, University of Alberta, Edmonton, AB, Canada T6G 2E3. 